\title{
EFEKTIVITAS TEMPERATUR DAN WAKTU PEMASAKAN TERHADAP AKTIVITAS ANTIOKSIDAN PADA SIRUP DAUN BINAHONG (Anredera cordifolia) MENGGUNAKAN VACUUM EVAPORATOR
}

\author{
Adi Syakdani ${ }^{1}$, Indah Purnamasari ${ }^{2}$, Dwi Okta Larassakti ${ }^{2}$ \\ ${ }^{1}$ Program Studi Teknik Kimia/Jurusan Teknik Kimia, Politeknik Negeri Sriwijaya \\ ${ }^{2}$ Program Studi Teknologi Kimia Industri/Jurusan Teknik Kimia, Politeknik Negeri Sriwijaya \\ *E-mail: adis@polsri.ac.id
}

\begin{abstract}
ABSTRAK
Umumnya, sirup dibuat dari buah-buahan yang mengandung gula. Namun, sirup juga bisa dibuat dari daun, salah satunya adalah daun binahong. Daun binahong mengandung senyawa fenol tinggi, asam askorbat dan antioksidan sebagai penangkal radikal bebas. Dalam membuat sirup, suhu dan waktu memasak adalah salah satu faktor penting dalam mendapatkan sirup berkualitas SNI. Proses pemasakan dan pemekatan sirup daun binahong menggunakan evaporator vakum dengan variasi suhu $\left(45,50\right.$ dan $\left.55^{\circ} \mathrm{C}\right)$ dan waktu $(30,60,90$ dan 120 menit). Dalam penelitian ini, aktivitas antioksidan sirup daun binahong diuji dengan metode DPPH (2,2-difenil-1-pikilhidrazil), uji viskositas dan uji organoleptik. Hasil terbaik dari analisis antioksidan dan organoleptik yang telah dilakukan adalah perlakuan suhu $50^{\circ} \mathrm{C}$ dengan waktu memasak 60 menit, dengan aktivitas antioksidan tinggi 60,3950\% dan lebih stabil selama penyimpanan. Selain itu, berdasarkan hasil analisis organoleptik, perlakuan rasa terbaik pada suhu itu adalah 3,28 (suka), warna 2,63 (dianggap suka) dan bau 1,78 (tidak suka).
\end{abstract}

Kata kunci: Antioksidan, daun binahong, evapoorasi, vakum, sirup.

\begin{abstract}
Generally, syrup is made from fruits that contain sugar. However, syrup also can be made from leaves, one of them is binahong leaves. Binahong leaves contain high phenol compounds, ascorbic acid and antioxidants as antidotes to free radicals. In making syrup, the temperature and cooking time is one of the important factors in getting SNI-quality syrup. The process of cooking and concentrating binahong leaves syrup use a vacuum evaporator with the variation of temperature $\left(45,50\right.$ and $\left.55^{\circ} \mathrm{C}\right)$ and time $(30,60,90$ and 120 minutes). In this research, the antioxidant activity of binahong leaves syrup was tested by DPPH (2,2-diphenyl-1picylhydrazyl) method, viscosity test and organoleptic test. The best results from the antioxidant and organoleptic analysis that have been carried out are the temperature treatment of $50^{\circ} \mathrm{C}$ with 60 minutes cooking time, with a high antioxidant activity of $60.3950 \%$ and more stable during storage. Moreover, based on the results of organoleptic analysis, the best treatment of taste at that temperature is 3.28 (likes), color 2.63 (considered like) and smell 1.78 (dislike).
\end{abstract}

Keywords: Antioxidants, binahong leaves, evaporation, syrup, vacuum.

\section{PENDAHULUAN}

Antioksidan adalah senyawa yang dapat menstabilkan radikal bebas dengan melengkapi kekurangan elektron yang dimiliki radikal bebas dan menghambat terjadinya reaksi berantai dari pembentukan radikal bebas. Menurut penelitian Selawa dkk. (2013), antioksidan berguna untuk mengatur agar tidak terjadi proses oksidasi berkelanjutan didalam tubuh. Antioksidan sintetik diketahui memiliki efek samping yang besar antara lain menyebabkan kerusakan hati (Kikuzaki 
dkk., 2002). Sehingga mendorong dilakukannya eksplorasi bahan alam sebagai sumber antioksidan alami berupa tanaman. Indonesia kaya akan tanaman herbal yang secara turun temurun telah digunakan sebagai ramuan obat tradisional. Salah satu tanaman herbal yang belum banyak dikenal masyarakat Indonesia yakni tanaman binahong.

Binahong (Anredera cordifolia) sering digunakan oleh masyarakat sebagai obat tradisional untuk menyembuhkan luka bakar, luka setelah operasi, rematik, asam urat, pembengkakan jantung, muntah darah, tifus, stroke, wasir, dan radang usus (Towaha, 2011). Beberapa zat kimia yang terkandung pada daun binahong yakni flavonoid, alkaloid, polifenol, triterpenoid dan saponin (Rochani, 2009) sebagai antioksidan. Flavonoid adalah suatu kelompok senyawa fenol terbesar ditemukan di alam (Harbone, 1987) dan binahong adalah salah satu tanaman yang mengandung antioksidan cukup tinggi berupa senyawa flavonoid.

Hingga saat ini pemanfaatan daun binahong yang dijual di pasaran mayoritas diolah sebagai bahan pembuatan teh maupun kapsul ekstrak binahong. Produk minuman dari daun binahong seperti teh maupun kapsul sudah membanjiri pasar, namun karakteristik konsumen Indonesia yang ingin mencoba minuman menyehatkan dengan bahan dasar yang sama tetapi dalam bentuk yang berbeda seperti sirup memberikan peluang yang menjanjikan. Selain itu, daun binahong umumnya diolah oleh masyarakat awam hanya dengan cara direbus. Oleh karena itu, salah satu bentuk pengolahan daun binahong yang sekaligus meningkatkan nilai tambahnya adalah dengan mengolah daun binahong menjadi sirup (Anief, 1994). Pada umumnya, pembuatan minuman daun binahong hanya melalui tahap perebusan, sehingga karakteristik sirup daun binahong masih sangat encer karena perbandingan air lebih banyak daripada zat aktif daun yang terlarut (Ratih dkk., 2015). Selain itu, perebusan yang dilakukan tanpa memperhatikan temperatur dan waktu pemasakan akan menyebabkan kerusakan pada senyawa-senyawa kimia yang terdapat dalam daun binahong sehingga akan mengurangi kadar antioksidan pada minuman daun binahong.

Dari uraian diatas, dapat diketahui bahwa temperatur dan waktu pemasakan merupakan faktor yang mempengaruhi kandungan senyawa flavonoid yang berperan sebagai antioksidan pada sirup daun binahong. Salah satu solusi untuk mengatasi permasalahan tersebut yakni daun binahong akan mengalami tahap pemasakan/perebusan dan pengentalan dengan temperatur dan waktu pemasakan tertentu menggunakan prototipe vacuum evaporator yang dirancang dengan prinsip menggunakan sistem vakum (kedap udara). Pengujian stabilitas produk yang dilakukan yakni dengan memperhatikan pengaruh temperatur, waktu pemasakan dan penyimpanan produk.

Tujuan penelitian ini adalah mendapatkan prototipe alat evaporator vakum, menentukan pengaruh temperatur dan waktu pemasakan terhadap viskositas dan aktivitas antioksidan sirup daun binahong, dan menentukan pengaruh lama penyimpanan terhadap kandungan antioksidan sehingga didapat kondisi operasi yang optimum untuk pengolahan daun binahong. Penelitian ini diharapkan dapat mengembangkan ilmu pengetahuan mengenai pengolahan daun binahong menjadi sirup dan teknologi mengenai perancangan vacuum evaporator yang dilengkapi sistem pengendalian. 


\section{METODE}

Penelitian ini dilakukan dengan perancangan evaporator vakum yang kemudian digunakan untuk pengolahan sirup daun binahong. Uji analisa yang dilakukan berupa viskositas, aktivitas antioksidan, dan organoleptik pada sirup daun binahong yang dihasilkan.

\section{Perancangan Evaporator Vakum}

Evaporator yang dirancang pada penelitian ini yakni evaporator vakum (tekanan di bawah $1 \mathrm{~atm}$ yaitu $\pm 0,614 \mathrm{~atm}$ ) jenis batch dengan kapasitas $8 \mathrm{~L}$, tinggi $17,69 \mathrm{~cm}$ dan diameter $24 \mathrm{~cm}$ yang dilengkapi dengan pengaduk dan sistem pengendali.

Pengendalian temperatur yang digunakan yakni pengendalian mode onoff otomatis. Sensor suhu yang digunakan yakni termokopel tipe $\mathrm{K}$ dengan thermal resistance temperature $(-200)-5000^{\circ} \mathrm{C}$. Pemilihan termokopel tipe $\mathrm{K}$ sebagai sensor suhu atas dasar pertimbangan harga yang terjangkau namun kinerja tetap baik serta tahan terhadap karat.

\section{Pembuatan Sirup Daun Binahong}

Tahap pertama yang dilakukan pada penelitian ini yakni pembuatan sirup daun binahong dengan vacuum evaporator yang telah dirangkai. Bahan utama yang dibutuhkan yakni daun binahong, gula, dan air. Daun binahong sebanyak $200 \mathrm{~g}$ dicuci lalu dihaluskan menggunakan blender dengan air sebanyak 2 L. Saring campuran daun binahong sehingga didapatkan sari binahong. Filtrat daun binahong kemudian dicampurkan dengan $1,6 \mathrm{~kg}$ gula pasir. Proses pemasakan dan pengentalan campuran daun binahong dengan gula pasir dilakukan menggunakan evaporator vakum dengan variasi waktu evaporasi $(30,60,90$, dan 120 menit) dan temperatur evaporasi $\left(45,50\right.$, dan $\left.55^{\circ} \mathrm{C}\right)$ sehingga dihasilkan sirup binahong.

\section{Uji Kinerja Sensor}

Tahap kedua yang dilakukan dalam penelitian ini adalah uji kinerja sensor. Uji kinerja sensor berupa pengukuran dan pengendalian terhadap variasi harga setpoint temperatur dan waktu. Hal ini bertujuan untuk menganalisis kestabilan sensor yang digunakan dan untuk melihat apakah dengan diterapkannya pengendalian, sistem tersebut mampu mencapai harga setpoint yang ditentukan.

\section{Pegukuran Viskositas}

Tahap ketiga pada penelitian ini adalah melakukan pengukuran viskositas sirup daun binahong. Metode yang digunakan yakni Metode Hoppler, dimana viskositas diukur berdasarkan lama waktu yang dibutuhkan untuk bola jatuh melalui cairan dalam tabung pada suhu tetap.

\section{Uji Antioksidan}

Tahap keempat pada penelitian ini adalah melakukan uji aktivitas antioksidan pada sirup daun binahong. Metode yang digunakan yakni Metode DPPH (2,2-diphenyl-1-picylhydrazyl) dengan menggunakan Spektrofotometer Agilent Technologies 8453 G1103A Diode Array UV/VIS. Uji antioksidan dilakukan pada hari ke-0, 4, 8, dan 12 . Daya pengikat radikal bebas dihitung dengan menggunakan rumus:

$$
\begin{aligned}
& \% \text { inhibisi } \\
& =\frac{\text { Abs Blanko }- \text { Abs Sampel }}{\text { Abs Blanko }} \times 100 \% \text { (1) }
\end{aligned}
$$

(Rahmawati dkk., 2012)

Ket: $\mathrm{Abs}=$ absorbansi

\section{Uji Organoleptik}

Pengamatan organoleptik yang dilakukan terhadap sirup daun binahong dilakukan dengan metode survei pada 
panelis standar berjumlah 2 orang dan panelis non standar minimal 30 orang. Analisa organoleptik yang dilakukan dalam penelitian ini meliputi rasa, aroma dan warna.

\section{HASIL DAN PEMBAHASAN}

Pengaruh Temperatur dan Waktu Pemasakan terhadap Viskositas Sirup Daun Binahong

Viskositas sirup daun binahong ditunjukkan pada Gambar 1. Dari grafik tersebut dapat diketahui bahwa nilai viskositas dari sirup daun binahong semakin tinggi dengan kenaikan temperatur dan lamanya waktu pemasakan. Menurut Buckle dkk. (1985), kekentalan suatu zat cair dengan penambahan gula tergantung pada lama waktu pemanasan. Semakin lama pemanasan dilakukan, sirup yang dihasilkan akan semakin kental. Hal ini dapat terjadi karena semakin tinggi daya suhu pemanasan maka semakin tinggi daya larut dari gula.

Jika dilihat pada Gambar 1, viskositas tertinggi pada temperatur pemasakan $55^{\circ} \mathrm{C}$ dan waktu 120 menit yakni sebesar $14,14 \mathrm{cP}$ sedangkan viskositas terendah pada temperatur pemasakan $55^{\circ} \mathrm{C}$ dan waktu 30 menit yakni sebesar $4,76 \mathrm{cP}$. Pada temperatur pemasakan $55^{\circ} \mathrm{C}$ waktu 30 menit dan 60 menit menunjukkan nilai viskositas yang lebih rendah dibandingkan pada temperatur 45 dan $50^{\circ} \mathrm{C}$ dengan waktu yang sama. Sedangkan secara teori semakin tinggi temperatur maka semakin banyak kandungan air yang teruapkan dan semakin tinggi viskositas cairan. Penyimpangan ini disebabkan karena terjadi kebocoran di sekitar pengaduk pada tutup tangki, terlihat pada pressure gauge di tutup tangki evaporator yang menunjukkan tekanan didalam sistem tidak stabil. Kebocoran tersebut menyebabkan kerja pompa vakum terganggu sehingga molekul uap air yang harusnya terhisap oleh pompa vakum menuju ke Catridge Filter Air jadi kembali lagi ke sistem.

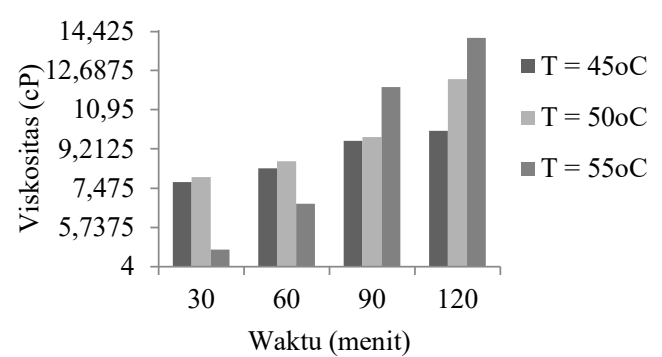

Gambar 1. Viskositas Sirup Daun Binahong Variasi Temperatur dan Waktu Pemasakan

Standar viskositas sirup sendiri belum ditetapkan oleh SNI sirup, sedangkan sirup di pasaran dalam hal ini sirup $\mathrm{ABC}$ memiliki viskositas sebesar $25 \mathrm{cP}$, itu artinya viskositas sirup daun binahong belum mencapai viskositas sirup yang beredar di pasaran. Hal ini disebabkan karena waktu pemasakan yang dilakukan kurang lama. Penggunaan waktu pemasakan yang tidak terlalu lama pada penelitian ini dilakukan untuk menjaga antioksidan yang terdapat pada sirup daun binahong agar tidak terdekomposisi, sehingga penggunaan waktu terlama yakni selama 120 menit. Rendahnya nilai viskositas juga disebabkan karena kurangnya penambahan gula pada sirup. Karena semakin tinggi konsentrasi gula yang diberikan, semakin tinggi pula tingkat viskositasnya. Menurut penelitian Pratama dkk. (2012) gula akan mengikat lebih banyak air, sehingga viskositas meningkat. Selain itu, semakin banyak komponen gula yang terlarut maka zat organik yang terlarut juga semakin banyak sehingga nilai viskositasnya juga semakin tinggi.
Aktivitas Antioksidan pada Sirup Daun Binahong berdasarkan Temperatur dan Waktu Pemasakan 
Adanya aktivitas antioksidan dari sampel mengakibatkan terjadinya perubahan warna pada larutan DPPH dalam metanol yang semula berwarna ungu berubah menjadi warna kuning. Perubahan ini terjadi saat radikal DPPH ditangkap oleh antioksidan yang melepas atom hidrogen untuk menangkap DPPH$\mathrm{H}$ stabil. Hasil penelitian nilai antioksidan pada sirup daun binahong dapat dilihat pada Gambar 2.

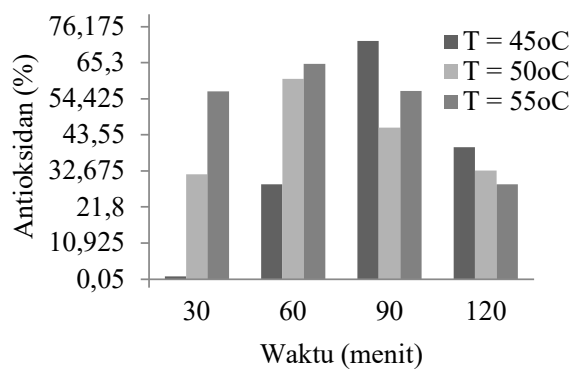

Gambar 2. Aktivitas Antioksidan berdasarkan Variasi Temperatur dan Waktu Pemasakan

Jika dilihat dari pada Gambar 2, sampel temperatur $45^{\circ} \mathrm{C}$ membutuhkan waktu lebih lama yakni 90 menit untuk antioksidan aktif atau mencapai kondisi maksimum yakni $71,87 \%$, sedangkan pada sampel temperatur 50 dan $55^{\circ} \mathrm{C}$ membutuhkan waktu yang lebih cepat yakni 60 menit untuk mencapai antioksidan maksimum masing-masing yaitu mencapai $60,39 \%$ dan $64,91 \%$. Itu artinya, untuk mencapai kondisi maksimum yang lebih cepat dengan temperatur yang tidak terlalu tinggi, pemasakan sirup daun binahong dengan evaporator vakum pada temperatur $50^{\circ} \mathrm{C}$ telah mampu melakukannya yakni dengan waktu pemasakan 60 menit dengan antioksidan maksimum. Hal ini disebabkan karena temperatur optimal yang digunakan pada pengolahan simplisia yaitu $30-60^{\circ} \mathrm{C}$ (Departemen Kesehatan RI, 1985).

Selain itu, hal ini juga membuktikan bahwa semakin tinggi temperatur dan semakin lama waktu pemasakan maka dapat menyebabkan terjadinya penurunan aktivitas antioksidan. Hal ini disebabkan karena terjadinya dekomposisi senyawa flavonoid karena flavonoid memiliki sifat termolabil (tidak tahan terhadap suhu panas) dan mudah teroksidasi pada suhu tinggi (Lusivera, 2002).

\section{Aktivitas Antioksidan pada Sirup Daun Binahong setelah Dilakukan Penyimpanan di dalam Kulkas}

Pada uji analisa ini, sirup daun binahong yang memiliki antioksidan tertinggi pada variasi temperatur 40,50 dan $55^{\circ} \mathrm{C}$ disimpan di dalam kulkas (temperatur $3-4^{\circ} \mathrm{C}$ ) kemudian diuji aktivitas antioksidannya pada hari ke 0 , 4, 8, dan 12. Pemilihan penyimpanan di dalam kulkas karena sirup yang disimpan pada suhu rendah mampu meredam aktivitas senyawa radikal bebas dengan lebih baik dibandingkan dengan sirup yang disimpan pada suhu tinggi. Hasil penelitian nilai antioksidan pada sirup daun binahong berdasarkan lama penyimpanannya dapat dilihat pada Gambar 3.

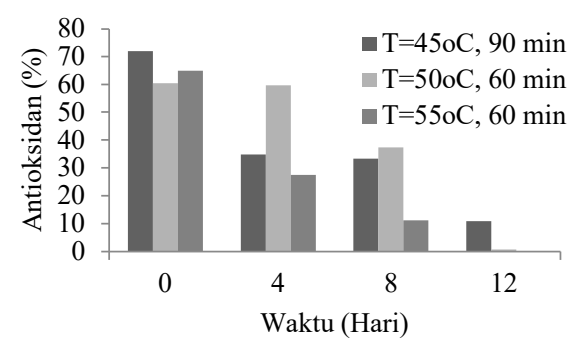

Gambar 3. Aktivitas Antioksidan berdasarkan Waktu Penyimpanan Sirup Daun Binahong

Jika dilihat dari Gambar 3 diatas dapat diketahui bahwa aktivitas antioksidan dalam mereduksi DPPH dalam sirup daun binahong yang dimasak pada temperatur $45^{\circ} \mathrm{C}$ selama 90 menit memiliki kemampuan terbaik pada hari ke-0 (awal pembuatan) sebesar $71,87 \%$. Setelah disimpan, aktivitas antioksidan dalam mereduksi DPPH 
terus menurun. Begitupun pada sirup daun binahong yang dimasak pada temperatur $50^{\circ} \mathrm{C}$ dan $55^{\circ} \mathrm{C}$ selama 60 menit, keduanya memiliki kemampuan terbaik pada hari ke-0, namun setelah dilakukan penyimpanan terjadi penurunan aktivitas antioksidan hari ke4, hari ke-8 dan hingga pada hari ke-12 sebesar $\quad 0 \% \quad$ (tidak terkandung antioksidan lagi).

Penurunan ini karena senyawa metabolit sekunder berupa flavonoid yang warnanya semakin memudar karena pengaruh cahaya saat penyimpanan maupun saat uji analisa (Dwiyanti dan Nurani, 2014). Seperti yang telah dijelaskan sebelumnya bahwa flavonoid mudah teroksidasi bila terkena cahaya. Hal ini menyebabkan menurunnya kualitas flavonoid dalam sirup daun binahong sehingga berpengaruh terhadap aktivitas antioksidannya. Jika dilihat dari grafik pada Gambar 3, penurunan antioksidan berdasarkan lamanya penyimpanan pada sirup binahong temperatur $50^{\circ} \mathrm{C}$ memiliki penurunan antioksidan yang lebih stabil dibandingkan yang lainnya.

\section{Hasil Analisa Organoleptik}

\section{Rasa}

Rasa menjadi parameter paling utama dan memiliki nilai bobot tinggi dalam menentukan nilai suatu makanan. Rerata skor kesukaan rasa hasil penilaian panelis terhadap organoleptik rasa sirup daun binahong bekisar antara 2,9-3,28 yang berarti kategori suka. Berdasarkan Syarat Mutu Sirup SNI 01-3544 (1994) gula yang terkandung dalam sirup minimal $65 \%$ dan menurut penelitian sebelumnya oleh Pratama (2012) sirup dengan konsentrasi gula sebesar $80 \%$ memiliki nilai kesukaan rasa tertinggi, sehingga penggunaan konsentrasi $80 \%$ dipilih sebagai konsentrasi gula dalam pembuatan sirup daun binahong pada penelitian ini. Adapun grafik rerata tingkat kesukaan rasa sirup daun binahong dapat dilihat pada Gambar 4 berikut:

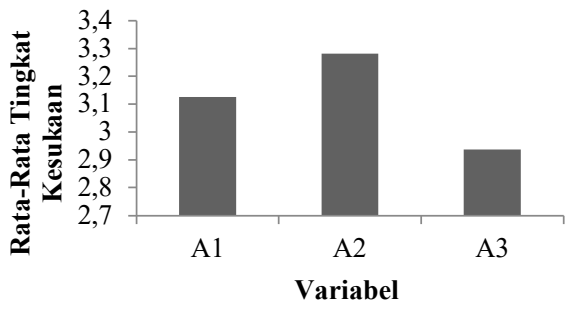

\section{Gambar 4. Tingkat Kesukaan Rasa Sirup Daun Binahong berdasarkan Uji Organoleptik}

Jika dilihat dari grafik tingkat kesukaan rasa pada sirup daun binahong terhadap temperatur pemasakan didapat nilai kesukaan terendah pada temperatur $55^{\circ} \mathrm{C}$ (A3) dan waktu pemasakan selama 60 menit dengan rata-rata nilai 2,94 dan nilai kesukaan rasa tertinggi pada temperatur $50^{\circ} \mathrm{C}$ (A2) dan waktu pemasakan yang sama yakni 60 menit dengan rata-rata nilai 3,28 , memiliki nilai yang tidak terlampau jauh. Berdasrkan hasil analisa sidik ragam (ANOVA) didapat nilai $\mathrm{F}$ hitung sebesar 2,01 dan $F$ tabel 3,09. Hal ini menunjukkan bahwa perbedaan temperatur dan waktu pemasakan menunjukkan tidak adanya pengaruh nyata terhadap penilaian organoleptik rasa pada ketiga perlakuan yang dapat dilihat dari nilai $\mathrm{F}$ hitung $<\mathrm{F}$ tabel.

\section{Aroma}

Rerata skor kesukaan aroma hasil penilaian panelis terhadap organoleptik rasa sirup daun binahong bekisar antara 1,63-2,19 yang berarti kategori kurang suka, seperti yang terlihat pada Gambar 5.

Gambar 5 menunjukkan bahwa nilai kesukaan panelis terhadap parameter organoleptik aroma tidak berbeda nyata antar perlakuan. Perbedaan tidak nyata ini dikarenakan panelis memang kurang menyukai aroma dari sirup daun 
binahong yang pada dasarnya daun binahong memiliki aroma yang kuat yaitu aroma khas daun. Hal ini didukung oleh hasil analisa sidik ragam (ANOVA) didapat nilai $\mathrm{F}$ hitung sebesar $-6,58$ dan $\mathrm{F}$ tabel 3,09. Hal ini menunjukkan bahwa perbedaan temperatur dan waktu pemasakan menunjukkan tidak adanya pengaruh nyata terhadap penilaian organoleptik aroma pada ketiga perlakuan yang dapat dilihat dari nilai $\mathrm{F}$ hitung $<$ F tabel.

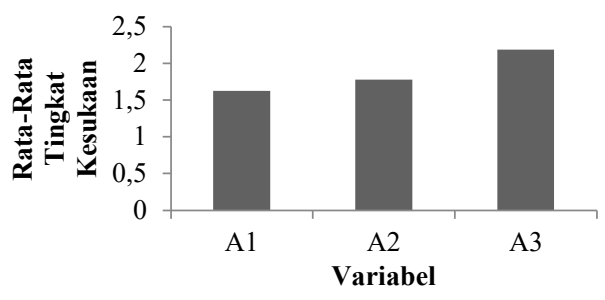

Gambar 5. Tingkat Kesukaan Aroma Sirup Daun Binahong berdasarkan Uji Organoleptik

\section{Warna}

Warna mempunyai peran penting pada komoditas pangan. Peranan ini sangat nyata pada tiga hal yaitu daya tarik, tanda pengenal, dan atribut mutu. Rerata skor kesukaan warna hasil penilaian panelis terhadap organoleptik warna sirup daun binahong bekisar antara 2-2,63 yang berarti kategori antara kurang suka dan suka, seperti yang terlihat pada Gambar 6 .

Jika dilihat dari grafik tingkat kesukaan warna pada sirup daun binahong terhadap temperatur pemasakan didapat nilai kesukaan terendah pada temperatur $55^{\circ} \mathrm{C}$ (A3) dengan waktu pemasakan selama 60 menit memiliki rata-rata nilai 2 dan nilai kesukaan warna tertinggi pada temperatur $50^{\circ} \mathrm{C}$ (A2) dengan waktu pemasakan yang sama yakni 60 menit memiliki rata-rata nilai 2,625.

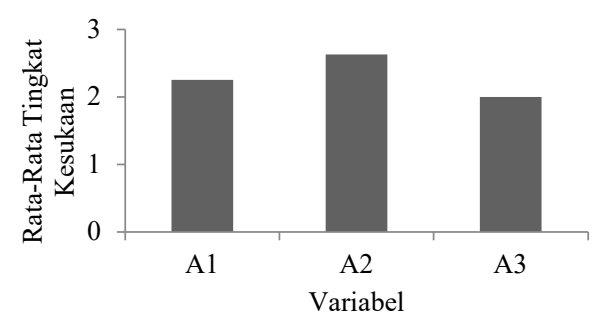

\section{Gambar 6. Tingkat Kesukaan Warna Sirup Daun Binahong berdasarkan Uji Organoleptik}

Hal ini disebabkan karena semakin tinggi temperatur pemasakan maka semakin pekat warna sirup daun binahong yang dihasilkan, begitupun pada waktu pemasakan. Semakin lama waktu pemasakan maka warna sirup yang dihasilkan semakin pekat seperti pada sampel A1 (temperatur $45^{\circ} \mathrm{C}$ waktu 90 menit). Sedangkan sirup daun binahong dengan temperatur pemasakan $50^{\circ} \mathrm{C}$ memiliki warna kekuningan (lebih pucat) dibandingkan dua sampel lainnya. Hal ini didukung oleh hasil analisa sidik ragam (ANOVA) didapat nilai $\mathrm{F}$ hitung sebesar 6,47 dan $F$ tabel 3,09. Hal ini menunjukkan bahwa perbedaan temperatur dan waktu pemasakan menunjukkan adanya pengaruh nyata terhadap penilaian organoleptik warna pada ketiga perlakuan yang dapat dilihat dari nilai $\mathrm{F}$ hitung $>\mathrm{F}$ tabel.

\section{SIMPULAN}

Dari hasil penelitian ini dapat disimpulkan bahwa alat evaporator vakum dengan tekanan operasi dibawah 1 atmosfer (kondisi vakum) berkapasitas $8 \mathrm{~L}$ dan dilengkapi dengan pengendalian On-Off dapat digunakan untuk menurunkan kadar air sehingga didapatkan sirup daun binahong yang kental dengan viskositas berkisar antara 4,76-14,14 cP. Semakin tinggi temperatur dan semakin lama waktu pemasakan maka viskositas sirup yang dihasilkan semakin besar dan aktivitas antioksidan semakin menurun. 
Semakin lama waktu penyimpanan sirup daun binahong maka aktivitas antioksidannya semakin menurun. Hasil terbaik dari analisa antioksidan dan organoleptik yang telah dilakukan adalah perlakuan temperatur $50^{\circ} \mathrm{C}$ dengan waktu pemasakan 60 menit, dengan aktivitas antioksidan yang cukup tinggi yakni sebesar $60,39 \%$ dan lebih stabil selama penyimpanannya. Selain itu, berdasarkan hasil analisa organoleptik, perlakuan terbaik terhadap rasa pada temperatur pemasakan $50^{\circ} \mathrm{C}$ dan waktu 60 menit yakni 3,28 (suka), warna 2,63 (dianggap suka) dan aroma 1,78 (kurang suka).

\section{DAFTAR RUJUKAN}

Anief, M. 1994. Farmasetika. Gadjah Mada University Press. Yogyakarta.

Buckle, K.A.M.; Edwards, G.H. dan Wooton, H. 1985. Ilmu Pangan (Terjemahan). Universitas Indonesia. Jakarta.

Departemen Kesehatan Republik Indonesia. 1985. Cara Pembuatan Simplisia. 1985. Jakarta. Hal: 10-11.

Dwiyanti, G. dan Nurani, H. 2014. Aktivitas Antioksidan The Rosela (Hibiscus sabdariffa) Selama Penyimpanan pada Suhu Ruang. Prosiding Seminar Nasional Sains dan Pendidikan Sains IX. Fakultas Sains dan Matematika, UKSW 5(1)

Harbone, J.B. 1987. Metode Fitokimia: Penentuan Cara Modern Menganalisis Tumbuhan. Institut Teknologi Bandung. Bandung.

Kikuzaki, H.; Hisamoto.; Hirose, K., Akiyama, K., dan Taniguchi, $\mathrm{H}$.
2002. Antioxidant Properties of Ferulic Acid and Its Related Compounds. Journal of Agricultur and Food Chemistry, 50(7): 21612168.

Lusivera, T.K., 2002. Mempelajari Pengaruh Pemanasan terhadap Kadar Flavonoid. Skripsi, Fakultas Teknologi Pertanian. Institut Pertanian Bogor. Bogor.

Pratama, B.S.; Wijana, S. dan Febriyanto, A. 2012. Studi Pembuatan Sirup Tamarillo (Kajian Perbandingan Buah dan Konsentrasi Gula). Jurnal Industria 1(3): 181194.

Ratih.; Nurlailah. dan Widiningsih, I.K. 2015. Efektivitas Air Rebusan Daun Binahong (Anredera Cordifolia) Terhadap Pertumbuhan Salmonella Typhi.Medical Laboratory Technology Journal 1:1-6

Rochani, N. 2009. Uji Aktivitas Antijamur Ekstrak Daun Binahong (Anrederacordifolia (Tenore) Steen) terhadap Candida Albicans serta Skrinning Fitokimianya. Skripsi. Fakultas Farmasi. Universitas Muhammadiyah Surakarta. Surakarta.

Selawa, W.; Runtuwene, J.R.M. dan Citraningtyas, G. 2013. Kandungan Flavonoid dan Kapasitas Antioksidan Total Ekstrak Etanol Daun Binahong (Anrederacordifolia (Ten.) Steenis). Jurnal Ilmiah Farmasi 2(1).

Towaha, J. 2011. Zat Aktif pada Tanaman Binahong. Majalah Semi Populer Tree 2(2). 